\title{
Crustal sources in Lower Palaeozoic rocks from NW Iberia: insights from laser ablation U-Pb ages of detrital zircons
}

\author{
J. FERNÁNDEZ-SUÁREZ1, G. GUTIÉRREZ-ALONSO², G. A. JENNER1 and M. N. TUBRETT1 \\ ${ }^{1}$ Department of Earth Sciences, Memorial University of Newfoundland, St John's NF. A1B 3X5 Canada \\ ${ }^{2}$ Departamento de Geologia, Universidad de Salamanca, 337700 Salamanca, Spain
}

\begin{abstract}
Detrital zircons from greywackes belonging to an Ordovician volcanosedimentary-igneous complex in NW Spain were dated using the laser ablation-inductively coupled plasma-mass spectrometry technique. $\mathrm{U}-\mathrm{Pb}$ results indicate the existence of three Pre-cambrian crustal sources in NW Iberia. The age grouping dated at c. 590-620 Ma confirms the presence of a Cadomian-Avalonian basement in this zone. The second age group (c. 1.1-1.2 Ga) is the first evidence for a Grenvillean age crustal component in NW Iberia. The age grouping dated at c. 1.9-2.0 Ga corresponds to the age of the Icartian igneous basement exposed in other areas of the European Variscides.
\end{abstract}

Keywords: NW Iberia, laser ablation methods, U-Pb, zircon.

Understanding the nature, age and distribution of basement terranes in orogenic zones provides constraints on the evolution of igneous and sedimentary rocks formed during subsequent orogenic cycles. Neodymium isotopic compositions and model ages of granitoids or detrital sedimentary rocks, for example, are often not uniquely interpretable without knowledge of the ages of crustal reservoirs that constituted sources for those granitoid melts or sedimentary detritus. Plate tectonic and paleogeographic reconstructions are also greatly aided by evidence about the age and distribution of older terranes. In this context, the Precambrian evolution of NW Iberia is poorly constrained owing to the lack of exposed preNeoproterozoic basement.

It is thought that NW Iberia was part of the Neoproterozoic assemblage of terranes that made up the Cadomian-Avalonian magmatic arc and associated basins developed on an active Gondwanan margin (e.g. Nance \& Murphy 1996). In these terranes there is abundant indirect evidence for the existence of an older pre-Neoproterozoic basement at depth (e.g. Nance \& Murphy 1996; Keppie et al. 1998). Direct evidence for preNeoproterozoic basement in Cadomian-Avalonian terranes, however, is rather scarce (data compilation in Nance \& Murphy 1996; Samson \& D’Lemos 1998). In NW Iberia, there

is little and somewhat controversial evidence for Archean (c. $2.7 \mathrm{Ga}$ ) and Palaeoproterozoic (c. $1.9 \mathrm{Ga}$ ) crustal components (Guerrot et al. 1989; Gebauer 1993).

In this paper we report $\mathrm{U}-\mathrm{Pb}$ single grain ages of zircons separated from Lower Ordovician volcanosedimentary rocks. The ages were obtained by using the laser ablation microprobe-inductively coupled plasma-mass spectrometry technique (LAM-ICP-MS). Our aim is to present new geochronological data, obtained by means of a novel technique, that will contribute both to a better understanding of the Proterozoic-Early Paleozoic evolution of NW Iberia and to integrate better this area into palaeogeographic reconstructions of circum-Atlantic Gondwanan terranes.

Geological setting and samples. Samples were collected from coastal outcrops in the core of the Ollo de Sapo antiform (Martínez-Catalán et al. 1977; Fig. 1). The rocks sampled belong to the Ollo de Sapo volcanosedimentary-igneous complex, which is made up of granitoids and volcanosedimentary rocks. U-Pb data indicate Lower Ordovician (c. 465-480 Ma) crystallization ages for the granitoids of the Ollo de Sapo complex (Lancelot et al. 1985; Valverde \& Dunning 1997). The Ollo de Sapo Complex appears as a narrow belt within the Central Iberian Zone at its boundary with the West Asturian Leonese Zone (Fig. 1).
The samples are coarse- (JG2), and medium- (JG3) grained feldspathic greywackes interpreted as immature sediments containing significant amounts of a re-deposited volcanic component (Ortega et al. 1996). Mineralogical and textural features such as the coarse grain-size, low sorting, high amount of matrix, occurrence of euhedral-subhedral quartz and

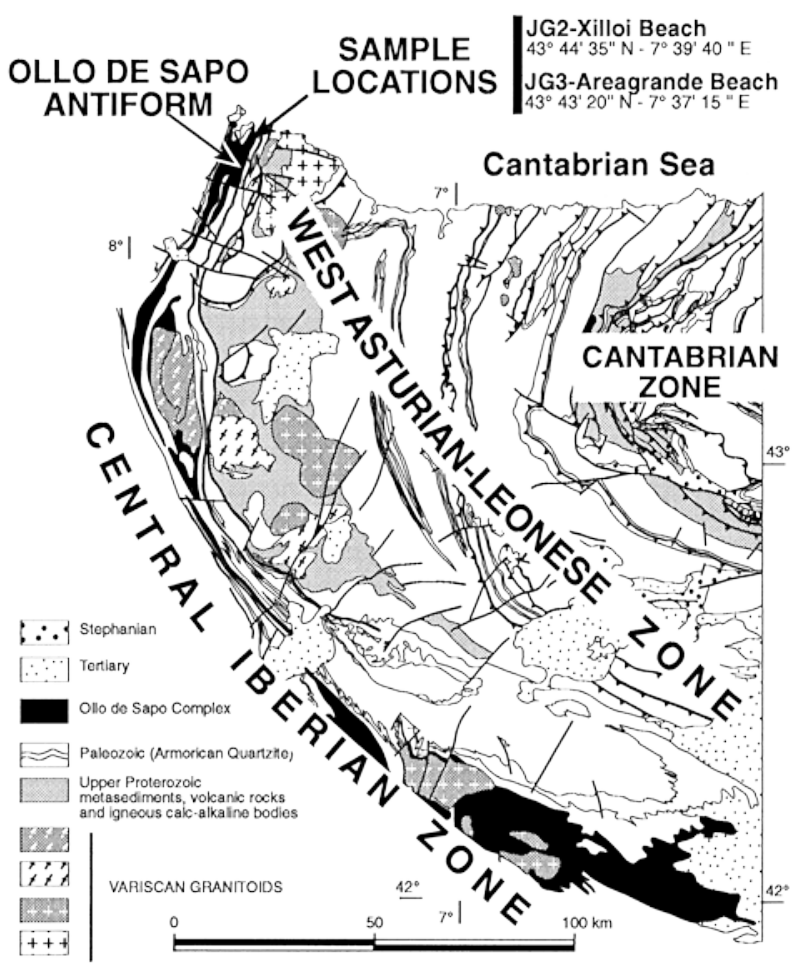

Fig. 1. Geological map of part of the NW Iberian Variscan belt showing the main units, tectonic features and granitoids. Location of samples collected for this study is also indicated. 
Table 1. Laser ablation ICP-MS U-Pb results

\begin{tabular}{|c|c|c|c|c|c|c|c|c|c|c|c|c|}
\hline Analysis & ${ }^{206} \mathrm{~Pb} /{ }^{238} \mathrm{U}$ & $\begin{array}{c}{ }^{206} \mathrm{~Pb} /{ }^{238} \mathrm{U} \\
\text { rsd(\%) }\end{array}$ & ${ }^{207} \mathrm{~Pb} /{ }^{235} \mathrm{U}$ & $\begin{array}{c}{ }^{207} \mathrm{~Pb} / 235 \\
\text { rsd(\%) }\end{array}$ & ${ }^{207} \mathrm{~Pb} /{ }^{206} \mathrm{~Pb}$ & $\begin{array}{c}{ }^{207} \mathrm{~Pb} / 206 \mathrm{~Pb} \\
\text { rsd(\%) }\end{array}$ & ${ }^{208} \mathrm{~Pb} /{ }^{232} \mathrm{Th}$ & $\begin{array}{l}{ }^{208} \mathrm{~Pb} /{ }^{232} \mathrm{Th} \\
\text { rsd(\%) }\end{array}$ & $\begin{array}{c}{ }^{206} \mathrm{~Pb} /{ }^{238} \mathrm{U} \\
\text { age (Ma) }\end{array}$ & $\begin{array}{c}{ }^{207} \mathrm{~Pb} / 235 \mathrm{U} \\
\text { age (Ma) }\end{array}$ & $\begin{array}{c}{ }^{207} \mathrm{~Pb} / 206 \mathrm{~Pb} \\
\text { age (Ma) }\end{array}$ & $\begin{array}{l}{ }^{208} \mathrm{~Pb} /{ }^{232} \mathrm{Th} \\
\text { age (Ma) }\end{array}$ \\
\hline \multicolumn{13}{|c|}{ Sample JG2 } \\
\hline $\mathrm{Z} 1$ & 0.3537 & 0.70 & 5.7980 & 1.10 & 0.1189 & 0.89 & 0.10200 & 0.80 & 1952 & 1946 & 1938 & 1963 \\
\hline $\mathrm{Z} 2$ & 0.1832 & 0.69 & 1.9224 & 1.51 & 0.07611 & 1.51 & 0.05145 & 4.64 & 1084 & 1089 & 1098 & 1014 \\
\hline Z3 & 0.1867 & 1.56 & 1.9251 & 1.20 & 0.07478 & 1.35 & 0.05106 & 1.99 & 1104 & 1090 & 1062 & 1007 \\
\hline $\mathrm{Z} 4$ & 0.0923 & 1.65 & 0.7694 & 3.27 & 0.06047 & 2.75 & 0.02678 & 2.99 & 569 & 579 & 620 & 534 \\
\hline Z5 & 0.0713 & 1.92 & 0.5507 & 3.97 & 0.05605 & 3.17 & 0.01992 & 3.76 & 444 & 445 & 454 & 400 \\
\hline Z6 & 0.0711 & 0.99 & 0.5315 & 3.99 & 0.05418 & 4.22 & 0.01870 & 4.08 & 443 & 433 & 380 & 374 \\
\hline \multicolumn{13}{|c|}{ Sample JG3 } \\
\hline $\mathrm{Z1}$ & 0.3568 & 1.09 & 5.9961 & 2.01 & 0.12189 & 1.90 & 0.08705 & 2.08 & 1967 & 1975 & 1984 & 1687 \\
\hline $\mathrm{Z} 2$ & 0.3353 & 0.96 & 5.7091 & 2.17 & 0.12349 & 2.27 & 0.09507 & 1.64 & 1864 & 1933 & 2006 & 1836 \\
\hline Z3 & 0.2015 & 0.57 & 2.1556 & 1.37 & 0.07760 & 1.46 & 0.05865 & 2.15 & 1183 & 1167 & 1136 & 1152 \\
\hline $\mathrm{Z} 4$ & 0.0967 & 0.80 & 0.8174 & 2.34 & 0.06133 & 2.32 & 0.02819 & 1.40 & 595 & 607 & 650 & 562 \\
\hline Z5 & 0.1002 & 0.59 & 0.7992 & 1.36 & 0.05782 & 1.28 & 0.02916 & 0.99 & 616 & 596 & 522 & 581 \\
\hline Z6 & 0.0965 & 2.68 & 0.7886 & 4.03 & 0.05925 & 2.32 & 0.03633 & 3.73 & 594 & 590 & 576 & 546 \\
\hline Z7 & 0.0739 & 0.71 & 0.5546 & 2.18 & 0.05440 & 2.06 & 0.02123 & 1.29 & 460 & 448 & 386 & 425 \\
\hline
\end{tabular}

feldspars, embayed quartz and zoned plagioclase suggest that: (i) these rocks derive mainly from the erosion of igneous sources and (ii) the sedimentary transport distance was short. This interpretation is further supported by the morphology of zircon grains, which were euhedral to subhedral, long to short prismatic or tabular with well developed crystal faces. Based on the above we consider that these greywackes are unlikely to contain zircons of exotic provenance.

Analytical methods. Laser ablation-inductively coupled plasma-mass spectrometry provides an alternative, relatively low cost method for $\mathrm{U}-\mathrm{Pb}$ dating of single zircon grains (Jackson et al. 1997). Zircons were separated using conventional techniques, hand picked and mounted on a synthetic resin. LAM ICP-MS instrumentation, analytical conditions and data reduction software, were developed at the Memorial University of Newfoundland (Jackson et al. 1997) and are only briefly commented upon here. The instrumentation consists of a laser ablation microprobe incorporating a frequency quadrupled Nd:YAG laser and an enhanced sensitivity ICP-MS. Using an imaged, defocused beam to reduce thermal edge effects and a novel ablation spot cooling Ar jet, minimal fractionation of $\mathrm{Pb}$ with respect to $\mathrm{U}$ is achieved. Calibration against a concordant mineral standard under constant ablation conditions is used to correct residual fractionation. Data are acquired in a time-resolved mode, allowing the use of depth-resolved signal and isotopic ratio profiles to detect zones enriched in common $\mathrm{Pb}, \mathrm{Pb}$ loss, inherited cores and other artifacts. All data reported here represent analyses of unzoned single zircon crystals. Zircon grains with a marked zonation or with a core/rim structure are easily detectable by inspection of the time-resolved U-Pb-Th isotopic ratio profiles and have been discarded since reliable analysis of different domains within a single grain are beyond the capability of the instrumentation used.

Results. Results of $\mathrm{U}-\mathrm{Pb}$ analyses on single zircon grains are reported in Table 1 and in the concordia diagrams of Fig. 2. Most analyses yielded within error concordant-subconcordant $\mathrm{U}-\mathrm{Pb}$ ages (Fig. 2).

Four age groupings are consistently represented in both samples (Table 1, Fig. 2): (1) c. 440-460 Ma; (2) c. 590$620 \mathrm{Ma}$; (3) c. 1080-1180 Ma; and (4) c. 1950-2000 Ma. The youngest $\mathrm{U}-\mathrm{Pb}$ age grouping (c. 440-460, Fig. 2a) is considered to represent the age of the volcanic component coeval with the deposition of the greywackes (see above).

Figure $2 \mathrm{~b}$ shows the three older recycled zircon populations within the greywackes. The youngest of these populations with an age range of c. 590-620 Ma (Fig. 2b, c) matches the crystallization ages of Cadomian granitoids in NW Iberia (Lancelot et al. 1985; Fernández-Suárez et al. 1998) and is interpreted to represent the recycling of Cadomian-Avalonian igneous rocks. The presence of this igneous basement is well documented in NW Iberia, which is considered to be one of the terranes that formed the Cadomian-Avalonian peripheral orogenic belt (Nance \& Murphy 1996; Keppie et al. 1998).

The second group (Fig. 2b, d) represents the recycling of a Mesoproterozoic crustal component of c. 1.10-1.20 Ga. Two zircons from sample JG2 yielded concordant data points with ${ }^{206} \mathrm{~Pb} /{ }^{238} \mathrm{U}$ ages of c. 1084 and $1104 \mathrm{Ma}$ and a zircon from sample JG3 yielded an older concordant data point with a ${ }^{206} \mathrm{~Pb} /{ }^{238} \mathrm{U}$ age of $c$. 1183 Ma. The presence of this Mesoproterozoic recycled crustal component has not been previously reported in NW Iberia.

The third group of recycled zircons (Fig. 2a, e) is represented by two concordant ages of $c .1950 \mathrm{Ma}\left({ }^{206} \mathrm{~Pb} /{ }^{238} \mathrm{U}\right.$ age, JG2) and c. $1984 \mathrm{Ma}\left({ }^{206} \mathrm{~Pb} /{ }^{207} \mathrm{~Pb}\right.$ age, JG3). A discordant zircon from JG3 yielded a ${ }^{207} \mathrm{~Pb} /{ }^{206} \mathrm{~Pb}$ age of $2006 \mathrm{Ma}$, within error limits of the concordant zircon from the same sample. These data are consistent with the existence of a c. 1.9-2.0 Ga crustal component in NW Iberia (Gebauer 1993). Slightly younger ages $(1.8-1.9 \mathrm{Ga})$ were reported from granulite boulders collected in the submarine environment of the northern coast of Spain (Guerrot et al. 1989). These ages correspond with the Icartian-Eburnean crust formation event recorded in different Gondwanan terranes of Africa and South America (e.g. Keppie et al. 1998 and references therein). In western Europe, similarly aged Palaeoproterozoic basement is represented by the Icart granitic orthogneisses $(2061 \pm 2 \mathrm{Ma})$ exposed in the Channel Islands (Samson \& D’Lemos 1998).

Discussion. The $\mathrm{U}-\mathrm{Pb}$ ages reported here indicate the occurrence of at least three Precambrian crustal sources that contributed detritus to the Ordovician greywackes. The nature of the source(s) that shed these zircon populations is debatable, as is often the case in provenance studies.

The Mesoproterozoic concordant ages at c. 1.1-1.2 Ga reveal the existence of a Grenvillean age component, which has important potential implications for the pre-Neoproterozoic evolution of Iberia. As in the Variscan realm of western Europe, there are no exposures of Grenvillean basement, various possibilities are compatible with the presence of 1.1$1.2 \mathrm{Ga}$ old zircons in the studied rocks: (i) they come from juvenile crust of Grenvillean age that is no longer exposed, (ii) they come from igneous rocks formed at $c .1 .1-1.2 \mathrm{Ga}$ by melting of pre-Grenvillean crust and (iii) they are derived 

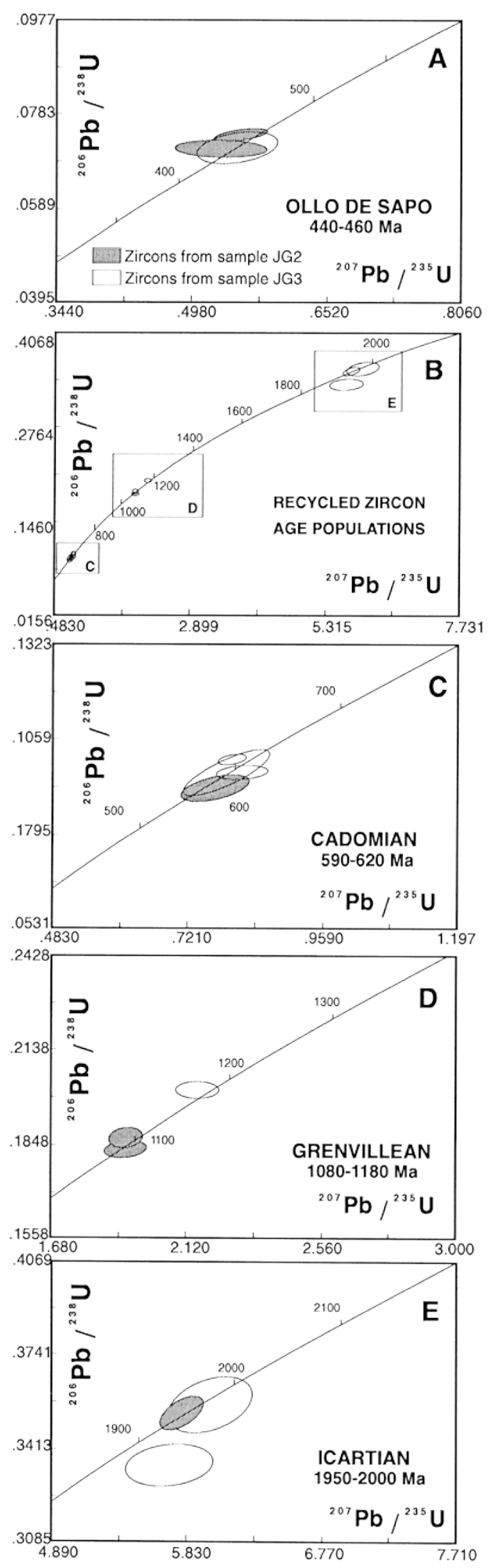

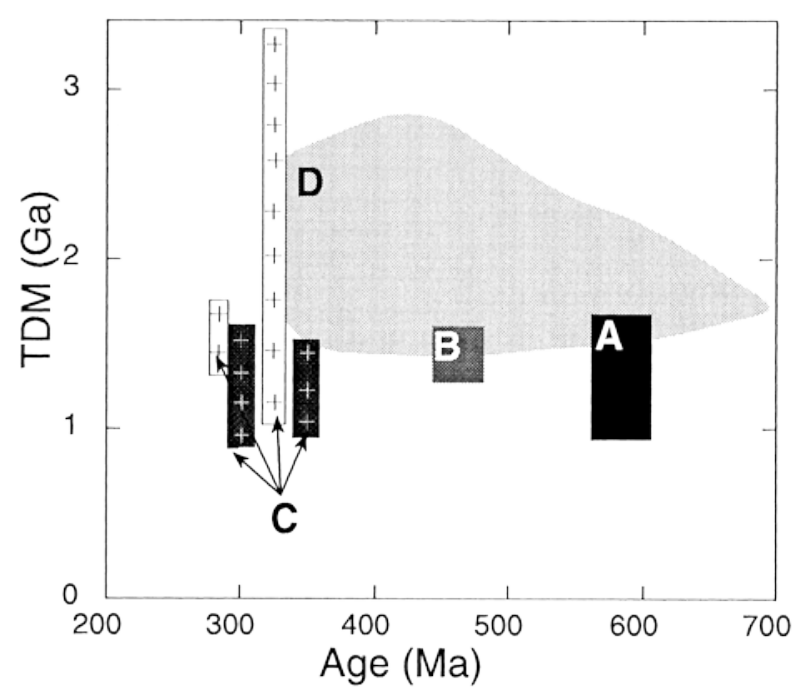

Fig. 3. Plot of $T_{\mathrm{DM}}$ v. age of granitoids and sedimentary rocks from Iberia and Cadomia (184 samples). Sources of data: A, Cadomian granitoids (D’Lemos \& Brown 1993; Samson \& D’Lemos 1998; Fernández-Suárez et al. 1998). B, Ollo de Sapo greywackes (Ortega et al. 1996). C, Variscan granitoids (white crosses, I-type granitoids; black crosses, leucogranites) (Beetsma 1995; Moreno Ventas et al. 1995; Galán et al. 1996; Villaseca et al. 1998; and own data). D, Sedimentary rocks (Beetsma 1995; Nägler et al. 1995).

from sedimentary formations containing detrital zircons of Grenvillean age. The morphologic characteristics of the zircons suggest a short transport distance from an igneous source.

As regards the Palaeoproterozoic age component (c. 1.9-2.0 Ga), several sources can also be envisaged: (i) igneous rocks similar to the 2 Ga granitoids exposed in the Channel Islands, (ii) zircons of this age were present as inherited xenocrysts in Grenvillean or Cadomian igneous sources, (iii) they are derived from a post-Icartian sedimentary formation. Case three is considered unlikely on the basis of zircon morphology. Case two seems also improbable given the concordant or near concordant ages of the Palaeoproterozoic zircons as significant lead loss is likely to occur if these zircons were once hosted in rocks that underwent high grade metamorphism and partial melting. We favour the idea that they were shed by an igneous source accreted at c. 1.9-2.0 Ga.

Our hypothesis is that the different age zircon populations found in the Ordovician greywackes were mainly derived from a multiage basement composed at least of Palaeoproterozoic (Icartian-Eburnean), Mesoproterozoic (Grenvillean) and Neoproterozoic (Cadomian-Avalonian) igneous rocks. Nevertheless, we do not rule out the possibility that part of the zircon population was derived from the exposed Neoproterozoic-Cambrian sediments or non-exposed preNeoproterozoic sedimentary rocks.

$\mathrm{Nd}$ isotopic signatures of igneous rocks provide additional indirect evidence for the nature of old basement sources. Infracrustal Cadomian-Avalonian granitoids from Iberia and Cadomia have a relatively narrow range of $T_{\mathrm{DM}}$ values (0.9-1.5 Ga) (Fig. 3) with most values clustering around 1.0$1.3 \mathrm{Ga}$. This signature is often attributed to a mixture of mantle melts of Cadomian extraction with an older component

Fig. 2. Concordia plots of U-Pb analytical data. Ellipses represent 2 uncertainties. Plot B is partially enlarged in plots C, D, and E. 
such as Icartian-type crust (D’Lemos \& Brown 1993). Although such a mixture can explain the Nd composition of those granitoids, it could also reflect the possible presence of a basement component with a broadly Grenvillean mantle extraction age. If that was the case, Cadomian granitoids with Grenvillean $T_{\mathrm{DM}}$ ages could represent melting of a juvenile crustal protolith of Grenville age (Fernández-Suárez et al. 1998). Therefore, the detrital zircon ages taken together with $\mathrm{Nd}$ isotopic signatures of Cadomian and Variscan granitoids are consistent with (but do not prove) the existence of a Grenvillean age component in the basement of NW Iberia.

A striking feature of the Ollo de Sapo rocks is their narrow range of $T_{\mathrm{DM}}$ ages (Fig. 3) in spite of the multi-age zircon population they contain. This reflects a relatively homogeneous mixture of crustal components (Icartian, Grenvillean, Cadomian and c. 440-460 Ma component) over a large area and is consistent with the proposed proximal nature of the crustal sources.

$T_{\mathrm{DM}}$ ages of Neoproterozoic to Carboniferous sedimentary rocks roughly image crustal events indicated by $\mathrm{U}-\mathrm{Pb}$ ages: the younger $T_{\mathrm{DM}}$ ages (Fig. 3) and lower $\mathrm{S}_{\mathrm{Nd}}$ values (Beetsma 1995; Näggler et al. 1995) recorded by Neoproterozoic sediments may reflect the addition of juvenile crust during the CadomianAvalonian event (c. 590-620 Ma). The oldest $\mathrm{T}_{\mathrm{DM}}$ ages and maximum spread of $\mathrm{T}_{\mathrm{DM}}$ values (Fig. 3) correspond to an age of c. 430-470 Ma (i.e. overlapping and following the Ollo de Sapo event). The combined $T_{\mathrm{DM}}$ and $\mathrm{S}_{\mathrm{Nd}}$ spread (Fig. 3, and Beetsma 1995; Näggler et al. 1995) reflect both an increase in the contribution from older crustal components and the addition of juvenile crust. We suggest that the increase in addition of older material could be related to the genesis of the Ollo de Sapo rocks in a crust undergoing progressive extension (see above). A progressively thinning crust is a likely scenario that would explain the simultaneous exhumation of lower crustal material and the generation of coeval magmatism.

A significant implication of this study concerns the location of Iberia in pre-Palaeozoic palaeogeographic reconstructions. Recent reconstructions of Gondwana during Late Proterozoic times show an arc edifice related to a subduction zone on its margin (Nance \& Murphy 1996; Keppie et al. 1998; Fernández-Suárez et al. 1998). This edifice was dismembered to form the different circum-North Atlantic terranes in which Avalonian-Cadomian tectonothermal events are recorded. Furthermore, in some of these terranes, such as West Avalonia, there is evidence for the existence of Grenvillean basement (e.g. Nance \& Murphy 1996). The possible presence of a Grenvillean basement component in NW Iberia might suggest that its Neoproterozoic location was closer to those terranes than previously thought (cf. Nance \& Murphy 1996; Keppie et al. 1998). Although the data presented and discussed here do not contribute conclusive evidence for such a possibility, they indicate that the role of Iberia in the Neoproterozoic evolution of Gondwana needs to be re-evaluated.

J.F.S. acknowledges a post-doctoral grant from the Spanish Ministry of Education. B. Bingen, G. E. Gehrels, L. P. Gromet and Grenville '1.1-1.2 Ga' Draper are kindly acknowledged. Financial support for this research was provided by an NSERC operating grant to G.A.J., an NSERC Major Facilities Access Grant for the ICP-MS facility (Memorial University) and a NATO travel grant to J.F.S., G.A.J. and F. Bea. Additional financial support to GGA was provided by DGIYCT project PB96-1452-C03-02.

\section{References}

Betsma, J.J. 1995. The late Proterozoic/Paleozoic and Hercynian crustal evolution of the Iberian Massif, $N$ Portugal, as traced by geochemistry and $\mathrm{Sr}-\mathrm{Nd}-\mathrm{Pb}$ isotope systematics of pre-Hercynian terrigenous sediments and Hercynian Granitoids. PhD Thesis, Vrije Universiteit, Amsterdam, The Nederlands.

D’Lemor, R.S. \& Brown, M. 1993. Sm-Nd isotope characteristics of of late Cadomian granite magmatism in northern France and the Channel islands. Geological Magazine, 130, 797-804.

Fernádnez-Suárez, J., Gutiérrez-Alonso, G. Jenner, J.A. \& Jackson, S.E. 1998. Geochronology and geochemistry of the Pola de Allande granitoids (northern Spain). Their bearing on the Cadomian/Avalonian evolution of NW Iberia. Canadian Journal of Earth Sciences, 35, 1439-1453.

Galán, G., Pin, C. \& Duthou, J.-L. 1996. Sr-Nd isotopic record of multi-stage interactions between mantle-derived magmas and crustal components in a collision context. The ultramafic-granitoid association from Vivero (Hercynian belt, NW Spain). Chemical Geology, 131, 67-91.

Gebauer, D. 1993. Intra-grain zircon dating within the Iberian Massif: Ollo de Sapo augengneisses, bimodal gneisses from the Massif de Guilleries (Girona), Graywacke of the Tentudía Group (serie Negra, SW Spain) and the HP/HT-rock association at Cabo Ortegal (Galicia). In: XII Reunião de Geologia do Oeste Peninsular, Comunicações, Evora. Portugal, 41-46.

Guerrot, C., Pelicat,, J.J., Capdevilla, R. \& Dosso, L. 1989. Archean protoliths within Early Proterozoic granulitic crus of the west European Hercynian belt: Possible relics of the west African craton. Geology, 17, 241-244.

Jackson, S.E., Longerich, H.P., Horn, I. \& Duunning, G.R. 1997. The application of Laser Ablation Microprobe (LAM)-ICP-MS to in situ U-Pb zircon geochronology. In: Proceedings of the Goldschmidt Conference, 283-284.

Keppie, J.D., D, D.W. \& K, T.E. 1998. U-Pb geochronological constraints on Precambrian stratified units in the Avalon Composite Terrane of Nova Scotia, Canada: tectonic implications. Canadian Journal of Earth Sciences, 35, 222-236.

Lancelot, J.R., Allegret, A. \& Iglesias, M. 1985. Outline of upper Pre- cambrian and Lower Paleozoic evolution of the Iberian Peninsula accord- ing to U-Pb dating of zircons. Earth Planetary Science Letters, 74, 325-337.

Martínez Catalçan, , J.R., González Lodeiro, F., Iglesias, M. \& Díez Balda, M.A. 1977. La estructura del domo de Lugo y el anticlinorio del Ollo de Sapo. Stvdia Geologica Salmanticensia, 12, 109-122.

Moreno-Ventas, I., Rpgers G. \& Castrp, A. 1995. The role of hybridization in the genesis of hercynian granitoids in the Gredos Massif, Spain: inferences from Sr-Nd isotopes. Contributions to Mineralogy and Petrology, 120, 137-149.

Nagler, T.F. Schafer, H.J. \& Gebauer, D. 1995. Evolution of the Western Europesn continental crust: implications from $\mathrm{Nd}$ and $\mathrm{Pb}$ isotopes in Iberian sediments. Chemical Geology (Isotope Geoscience Section), 121, 345-347.

Nance, R.D. \& Murphy, J.B. 1996. Basement isotopic signatures and Neoproterozoic paleogeography of Avalonian-Cadomian and related terranes in the Circum-North Atlantic. In: N, R.D. \& T, M.D. (eds) Avalonian and Related Peri-Gondwanan Terranes of the Circum-North Atlantic. Geological Society of America Special Paper 304, 109-120.

Ortega, L.A., Carracedo, M., Larrea, F.J. \& Gil Ibarguchi, J.I. 1996. Geochemistry and tectonic enviroment of Volcanosedimentary rocks from the Ollo de Sapo Formation (Iberian Massif, Spain). In: D, D. (ed.) Petrology and Geochemistry of magmatic suites of rocks in the continental and oceanic crusts. A volume dedicated to Professor Jean Michot. Université Libre de Bruxelles. Royal Museum for Central Africa (Tervuren), 277- 290.

Samson, S.D. \& D’Lemos, R.S. 1998. U-Pb geochronology and Sm-Nd isotopic composition of Proterozoic gneisses, Channel Islands, UK. Journal of the Geological Society, London, 155, 609-618.

Valverde Vaquero, P. \& Dunning, G.R. 1997. Magmatismo "Sárdico" Arenig en el Dominio del Ollo de Sapo de la Zona Centro Ibérica: Nuevas evidencias $\mathrm{U}-\mathrm{Pb}$ en la Sierra de Guadarrama. In: XIV Reunião de Geologia do Oeste Peninsular. Evolução Geológica do Maciço Ibérico e seu enquadramento continental, Comunicações, Vila Real, Portugal, 265-270.

Villaseca, C., Barbero, L. \& Rogers, G. 1998. Crustal origin of Hercynian peraluminous granitic batholiths of Central Spain: petrological, geochemical and isotopic (Sr, Nd) constraints. Lithos, 43, 55-79. 